\title{
Does Physical Disability Affect Children's Choice of Toys?
}

\author{
Bedensel Engelli Olmak Çocukların Oyuncak Seçimini Etkiler Mi? \\ DSelda Ateş Beşirik, ĐAyşe Sonay Türkmen \\ Karamanoğlu Mehmetbey University, Faculty of Health Science, Pediatric Nursing Department, Karaman, Turkey
}

\begin{abstract}
Aim: This research was carried out to determine the factors affecting the toy selection of physically disabled children.
\end{abstract}

Material and Method: 19 children, 19 mothers and 10 teachers participated in this study, which used a qualitative research design. The data were collected through a structured interview with the 'Data Collection Form' consisting of similar questions about the toy. The researcher interviewed the child, mother and teacher separately and alone. While analyzing the sociodemographic characteristics of the data, frequency, mean, standard deviation were used. Content analysis was carried out in the qualitative dimension of the research and the main themes were determined and interpreted by the researchers.

Results: When the answers given to the "toy definition" in the research were examined, the children emphasized that the toy should be "fun", while mothers and teachers emphasized that it was "useful", "educative and instructive". When the answers given to the 'toy selection' are examined, it is seen that the children's should be 'color' and 'of their own will', and that should be 'chosen by the children', 'quality and healthy', 'appropriate for their age', 'inexpensive' and 'according to the disability' by mothers and teachers. When the responses to the 'toy perception' were analyzed, it was emphasized that children should be 'gender-specific', while mothers and teachers should not be 'gender-specific.' When the answers given to the "added information about the toy" were examined, it was determined that the children should be toys "according to my mobility and disability" and that the mothers should be "more development toys for the physically disabled".

Conclusion: In this study, it was determined that being physically disabled affects the toy selection of children and especially mothers.

Keywords: Physically disabled, child, toy, toy selection

\section{ÖZ}

Amaç: Bu araştırma, bedensel engelli olan çocukların oyuncak seçimini etkileyen faktörleri belirlemek amacıyla yapıldı.

Gereç ve Yöntem: Nitel araştırma deseni kullanılan bu araştırmaya 19 çocuk, 19 anne ve 10 öğretmen katıldı. Veriler oyuncak ile ilgili benzer sorulardan oluşan 'Veri Toplama Formu' ile yapılandııımış görüşme yapılarak toplandı. Araştırmacı çocuk, anne ve öğretmen ile ayrıayrıveyalnızgörüştü.Verilerin sosyodemografiközelliklerinin analizi yapılırken frekans, ortalama, standart sapma kullanıldı. Araştırmanın nitel boyutunda içerik analizi yapılmış ve ana temalar araştırmacılar tarafından belirlenmiş ve yorumlanmıştır.

Bulgular: Araştırmada 'oyuncak tanımı' verilen yanıtlar incelendiğinde oyuncağın çocuklar 'eğlenceli', anneler ve öğretmenler ise 'faydalı', 'eğitici ve öğretici' özellikte olmasını vurguladı. 'Oyuncak seçimi' ile ilgili verilen yanıtlar incelediğinde çocukların oyuncağın 'renk' ve 'kendi isteği', annelerin ve öğretmenlerin ise 'çocukların seçmesi', 'kaliteli ve sağlıklı,' 'yaşına uygun', 'ucuz olması' ve 'engel yerine göre' olması gerektiği belirlendi. 'Oyuncak algısı' ile ilgili verilen yanıtlar incelediğinde çocukların 'cinsiyete özgü', annelerin ve öğretmenlerin ise 'cinsiyete özgü olmaması' gerektiği vurgulandı. 'Oyuncak ile ilgili eklenen bilgiler' ile ilgili verilen cevaplara bakıldığında çocukların 'hareketimi sağlama ve engelime göre' oyuncak olması annelerin ise 'bedensel engelli bireyler için daha geliştirici oyuncaklar olması' gerektiği belirlendi.

Sonuç: Bu araştırmada bedensel engelli olmanın çocukların ve özellikle annelerin oyuncak seçimini etkilediği saptandı.

Anahtar Kelimeler: Bedensel engelli, çocuk, oyuncak, oyuncak seçimi

Başvuru Tarihi/Received: 14.12 .2021 Kabul Tarihi/Accepted: 28.12.2021 


\section{INTRODUCTION}

The game continues by developing and changing in every period of life, starting with the life of the individual. It is the most satisfying resource for children to meet different learning and needs. Playing with toys starting from infancy are very important tools that they play tirelessly and develop certain motor skills. It maintains its importance throughout childhood (1-4). Play, which is natural, enriched and structured, is the most valuable developmental and reinforcing opportunity for children's lives (5).

Toy; It is all play equipment that regulates the child's movements throughout his development, supports his physical, mental and psychosocial development, and ensures the development of his creativity and abilities. From this point of view, in line with the literature, it can be said that the place and importance of toys is as great as play, especially in preschool and school periods (6-9).

Toys, which are an integral part of children's play, not only improve their social, mental, developmental and cognitive skills, but also have a significant impact on their play orientation and play theme $(10,11)$. In addition to the features they have, toys also provide benefits at different levels for children to acquire and develop different abilities. For example, toys such as dolls, robots and cars enable children to acquire versatile abilities and support all aspects of development. Materials such as legos, play dough, and intelligence cards support children to gain skills in different areas (11). Pehlivan (2005), on the other hand, emphasized that there are some features that parents, families and teachers should pay attention to when choosing toys (4). Toys; It should have features such as the child's age, level of development, interest, desire, needs, to develop imagination, and to be used safely. Apart from these, the gender, physical and mental characteristics of the child, which are among the other factors affecting the choice of toys, are also very important (12). The choice of toys is very important for children with disabilities. Especially parents and teachers of the child should pay attention to the choice of toys. In addition, children with physical disabilities have a great role in developing their perception of toy selection and play.

Apart from the child, there are two other parties associated with the toy around the child. The first of these is the parents, who allocate a budget for the toy economically and determine which toy to buy in line with the wishes and expectations of their child or themselves. The second is teachers who buy toys for educational institutions, guide children to use toys physically and functionally, and have the opportunity to use toys educationally (13). Although the choice of toys is important for the development of the child, a very limited number of studies have been found in the literature $(1,5,8,9,11,13)$, and no study has been found on the choice of toys for children with physical disabilities. For this reason, in this study, the views of physically disabled children, their mothers and teachers on the choice of toys were discussed.

\section{The aim of the research}

This research was carried out to determine the factors affecting the toy selection of physically disabled children.

\section{Research Questions}

- What are the factors affecting the choice of toys for children with physical disabilities?

- What are the factors affecting the choice of toys by mothers of children with physical disabilities?

- What are the factors affecting the choice of toys by teachers of children with physical disabilities?

\section{MATERIAL AND METHOD}

\section{Type of Research}

This research; qualitative research design was used.

\section{Population and Sample of the Research}

Population of the research: The universe of the research was carried out with all children aged 3-12 years attending Special Education and Rehabilitation Centers in Karaman City Center between 01 December 2018 and 15 January 2019. A total of 24 children, 24 mothers and 10 teachers, consisting of mothers and teachers with children in this age group.

Sample of the research: The 'convenience sampling' technique was used to determine the sample size of the study. Since the number of participants could not be predicted in qualitative studies, data collection was continued until the most detailed data on the main concept themes and questions of the research were reached. All children who met the inclusion criteria, their mothers and teachers were included in the sample. A total of 19 children, 19 mothers and 10 teachers participated in the research.

Inclusion criteria of the research; the child's age is between 3-12 years old, the child has any physical disability, and the informed consent form has been approved verbally and in writing.

Exclusion criteria of the research; it is the presence of parents and children who do not understand the questions, the child has a developmental delay/ inadequacy, communication and speech difficulties.

A total of five children and five mothers were excluded from the study because children and mothers gave incomplete answers to the questions. 


\section{Data Collection Instrument}

"Data Collection Form" was used to obtain the research data. In qualitative research, different data collection methods such as interview, observation and document analysis can be used (14). Since this research is both a qualitative study and aims to determine the perspectives of the participants on the research topic, 'interview' was chosen as the data collection technique. Interviewing is the most appropriate data collection method to collect data on the thoughts and perceptions of others and to capture the diversity and differences in perspectives (15).

Data collection form: In the study, data were collected with a semi-structured "Data Collection Form" developed by the researchers in accordance with the purpose of the research. The questions in this form were developed by utilizing various literature on the research topic and previous studies $(1,3,5,16,17)$. The data collection form prepared was evaluated by three experts serving at different universities, whether it measured the feature to be measured, its clarity, scope, etc. considered from different angles. After receiving expert opinions, the data collection form was rearranged. The form consists of 4 parts. In the first part, 12 questions containing the demographic information of the parents (such as age, number of children, education and job status), in the second part, 12 questions about the child's descriptive information and toy selection, in the third and fourth part, 9 separate questions containing the opinions of the mother and the teacher about the choice of toys. There are questions. There are multiple choice questions and open-ended questions in the data collection form, which consists of 42 questions in total.

Collection of data: After the researcher determined the children who met the sample selection criteria, informed consent form was prepared separately for the childmother-teacher, giving information about the purpose and content of the study and an informed written consent form was obtained from those who agreed to participate in the study. In addition, an interview environment was provided where the interviewer and the participated were alone and were not disturbed by anyone. Interviews were held at a suitable time for the researcher and the participant. The interviews were conducted face-to-face and one-on-one in a suitable room (with a chair, quiet, well-ventilated, light) sitting opposite each other. Data were collected by applying the "Data Collection Form" prepared by the researcher. The questions were asked directly to the participants by the researcher, and the answers were written down and recorded by the researcher immediately. The application time of the form took approximately 20 minutes.

\section{Ethical Aspect of Research}

The study was carried out with the permission of Karamanoğlu Mehmetbey University, Faculty of Health Science Non-interventional Clinical Research Ethics
Committee (Date: 28.11.2018, Decision No: 10/201838). Institutional permissions were obtained from the relevant institutions. Before starting the study, all children, their mothers and teachers were informed about the purpose, duration, plan of the study, and how the collected data would be used, through the "Informed Voluntary Consent Form" and their verbal and written consents were obtained.

\section{Statistical Analysis}

Data were analyzed in computer environment using SPSS 21 package program. Descriptive statistics (number, percentage, mean, standard deviation) test was used to analyze the descriptive characteristics of the participants. The answers given about the toy choices of the child, mother and teachers were evaluated using content analysis. Analysis of answers to open-ended questions is one of the most common and classic examples of content analysis (18). Content analysis was done by both researchers independently, then the results were compared and finalized. When evaluating the data, they were coded according to the questionnaire numbers (Child: C, Mother: M, Teacher: T; C2, M5 T6 etc.).

\section{RESULTS}

The families and the children descriptive characteristics are summarized in Table 1. In the study, it was found that the mean age of the mothers was $35.94 \pm 6.76$. It was determined that $68.4 \%(n=13)$ of the mothers were married. It was determined that $42.1 \%(n=9)$ of the mothers were secondary school and $94.7 \%(n=18)$ of the mothers were housewife. It was determined that $52.6 \%(n=10)$ of the family type was nuclear family. It was determined that $94.7 \%(n=18)$ of the family's monthly income was moderate and $68.4 \%(n=13)$ of social security existed. The mean number of children in the family was $2.36 \pm 1.46$ and it was $52.6 \%(n=10)$ to be the first child. It was determined that $63.2 \%(n=12)$ of the children were boys and the mean age of the children was $7.15 \pm 3.09$ (Table 1).

In this section, there are evaluations of the answers given to similar questions directed to the child, mother and teacher through interviews.

In the interview, each child, mother and teacher were asked 'What is a toy?', 'What should you pay attention to when buying a toy?', 'Can you tell me the first two toys that come to mind when you say a toy?', 'Is the toy useful for you?', 'Another toy?, 'Does it affect your choice?', 'Who chooses the toy?', 'Does the opposite sex play with the toy?', 'If the color of the toy is important to you, what color would you like it to be?' and 'Is there anything else you want to say about toys?' Nine questions were asked. The answers to the nine questions were evaluated in terms of content and gathered under four categories (toy definition, selection, perception and added information about the toy) and given in Table 2, Table 3 and Table 4. 
Table 1. Family and descriptive characteristics

\begin{tabular}{|c|c|c|}
\hline \multicolumn{2}{|c|}{ Family and Child Characteristics } & \multirow{2}{*}{$\begin{array}{c}\mathbf{n}(\%) \\
27-49 \\
35.94 \pm 6.76\end{array}$} \\
\hline Mother age (years) & $\begin{array}{l}\text { Min-Max } \\
\text { Mean } \pm S D\end{array}$ & \\
\hline Marital status & $\begin{array}{l}\text { Married } \\
\text { Divorced }\end{array}$ & $\begin{array}{l}13(68.4) \\
6(31.6)\end{array}$ \\
\hline Mother education status & $\begin{array}{l}\text { Reader-writer } \\
\text { Primary school } \\
\text { Middle School } \\
\text { High school }\end{array}$ & $\begin{array}{l}2(10.5) \\
5(26.3) \\
9(47.4) \\
3(15.8)\end{array}$ \\
\hline Mother's employment status & $\begin{array}{l}\text { Housewife } \\
\text { Working }\end{array}$ & $\begin{array}{c}18(94.7) \\
1(5.3)\end{array}$ \\
\hline Family type & $\begin{array}{l}\text { Nuclear family } \\
\text { Extended family } \\
\text { Broken family }\end{array}$ & $\begin{array}{c}10(52.6) \\
3(15.8) \\
6(31.6)\end{array}$ \\
\hline Your monthly income & $\begin{array}{l}\text { Good } \\
\text { Middle }\end{array}$ & $\begin{array}{c}1(5.3) \\
18(94.7)\end{array}$ \\
\hline Your social security & $\begin{array}{l}\text { Yes } \\
\text { No }\end{array}$ & $\begin{array}{l}13(68.4) \\
6(31.6)\end{array}$ \\
\hline Number of children & $\begin{array}{l}\text { Min-Max } \\
\text { Mean } \pm S D\end{array}$ & $\begin{array}{c}1-6 \\
2.36 \pm 1.46\end{array}$ \\
\hline This is the last child & $\begin{array}{l}\text { First child } \\
\text { Second and } \otimes\end{array}$ & $\begin{array}{l}10(52.6) \\
9(47.4)\end{array}$ \\
\hline Child's gender & $\begin{array}{l}\text { Girl } \\
\text { Boy }\end{array}$ & $\begin{array}{c}7(36.8) \\
12(63.2)\end{array}$ \\
\hline Child's age & $\begin{array}{l}\text { Min-Max } \\
\text { Mean } \pm S D\end{array}$ & $\begin{array}{c}4-12 \\
7.15 \pm 3.09\end{array}$ \\
\hline
\end{tabular}

As seen in Table 2, when the answers given under the title of "toy definition" were analyzed, it was found that the children should have the characteristics of "fun", "beauty", "seeing a friend" and "distraction", respectively. When the answers given under the title of "toy selection" were analyzed, it was determined that the children's toy should have the characteristics of "color", "self-will", "selection with the family", "cheap" and "family desire", respectively. When the answers given under the title of 'toy perception' of children were analyzed, it was determined that the toy should have 'gender-specific', 'both genders' and 'useful' features, respectively. It was determined that the first rank among the children's answers to the 'added information about the toy' should be the toy 'according to my mobility and disability' (Table 2).

As seen in Table 3, when the answers given by the mothers under the title of "toy definition" were analyzed, it was determined that the toy should have features such as "useful", "educational and instructive", "passing time", "distraction" and "useful for the disabled", respectively. When the answers given by the mothers under the title of 'toy selection' are analyzed, the characteristics of the toy are 'children choose', 'we choose together', 'parents' choice', 'quality and healthy', 'appropriate for age', 'cheap' and 'according to the disability'. When the

\begin{tabular}{|c|c|c|c|c|}
\hline Child and & Disability location & Toy definition & Toy selection & Toy perception \\
\hline C1-B & Foot & Car & to be robust & Car, truck \\
\hline C2-B & Arm & See it as a friend & to be cheap & Rubik's Cube \\
\hline C3-B & Arm & Truck & What colour is it & Tsar \\
\hline C4-G & Hand and foot & Baby & Fun toy & Muzeyyen baby \\
\hline C5-B & Arm & Balloon & Nothing & Lego \\
\hline C6-B & Arm and leg & Race car & What colour is it & Race car \\
\hline C7-B & Arm and leg & To enjoy & for the price & Fire Department \\
\hline C8-G & Arm and leg & Educational & to your beauty & kitchen set \\
\hline C9-B & Leg & The vehicle we play & be cheap & Robot \\
\hline C10-B & Foot & Fun vehicle & Colour & Robot, car \\
\hline C11-G & Foot & Baby & to have one & Baby \\
\hline C12-G & Arm and leg & Fancy baby & to be cheap & Baby \\
\hline C13-B & Leg & Funny & Cheap & Car, mirror toy \\
\hline C14-B & Foot & Funny, pass the time & Battery toys & Remote control car, airplane \\
\hline C15-B & Foot & Funny & Can be played with hands and feet & Anything can be a toy \\
\hline C16-G & Leg & $\begin{array}{l}\text { My most precious possessions } \\
\text { are my friends }\end{array}$ & It's pretty, babies have long hair & Baby dinnerware \\
\hline C17-B & Leg & Pass the time & Funny & Taxi bucket \\
\hline C18-G & Foot & Baby & Beautiful & Baby \\
\hline C19-G & Arm & Plane & What colour is it & Astronaut \\
\hline & & $\begin{array}{l}\text { Features highlighted in } \\
\text { definitions }\end{array}$ & Features highlighted in toy selection & $\begin{array}{l}\text { Features highlighted in toy } \\
\text { perception }\end{array}$ \\
\hline & & $\begin{array}{l}\text { Fun (9) } \\
\text { Beauty (3) } \\
\text { See friend (2) } \\
\text { Distraction (2) }\end{array}$ & $\begin{array}{l}\text { Color (17) } \\
\text { Own request (10) } \\
\text { Choosing with family (5) } \\
\text { Cheap (5) } \\
\text { Family request (4) }\end{array}$ & $\begin{array}{l}\text { Gender specific (12) } \\
\text { Both genders can play (7) } \\
\text { Useful (6) }\end{array}$ \\
\hline & & \multicolumn{3}{|c|}{ Added information about the toy } \\
\hline & & \multicolumn{3}{|c|}{$\begin{array}{l}\text { According to my mobility and disability (6) } \\
\text { Studying is more beneficial (1) }\end{array}$} \\
\hline
\end{tabular}


answers given under the title of 'toy perception' of the mothers were analyzed, it was determined that the toy should be 'non-gender specific', 'color perception' and 'baby' characteristics, respectively. Among the answers given by mothers to 'added information about toys', the first place was 'to have more developmental toys for physically disabled individuals', 'quality, healthy and harmless', 'educational and developmental', 'cheap' and 'no hard objects' (Table 3).

As seen in Table 4, when the answers given under the title of "toy definition" were analyzed, it was determined that the teachers should have the characteristics of "useful", "educative and instructive", "supporting fine, gross motor and mental development" and "communication tool", respectively. When the answers given under the title of 'toy selection' were analyzed, it was determined that the teachers should have the characteristics of 'children's choice', 'healthy-quality-harmless', 'colors', 'easily accessible' and 'cheap and everyone should be able to buy', respectively. When the answers given under the title of 'toy perception' of the teachers were analyzed, it was determined that the toy should be 'toy that both genders can play', respectively. Among the teachers' responses to 'added information about the toy', it was found that 'children do not discriminate in toys', 'tools for starting real life' and 'children should be able to do it themselves' (Table 4).

\begin{tabular}{|c|c|c|c|c|}
\hline $\begin{array}{l}\text { Mother and } \\
\text { child's gender }\end{array}$ & $\begin{array}{l}\text { Disability } \\
\text { location }\end{array}$ & Toy definition & Toy selection & Toy perception \\
\hline M1-B & Foot & $\begin{array}{l}\text { Educational, instructive, useful for his } \\
\text { disability }\end{array}$ & Appropriate for age and disability & House, baby \\
\hline M2-B & Arm & Fun, entertaining & $\begin{array}{l}\text { Being an educational and enjoyable } \\
\text { toy }\end{array}$ & Ball, baby \\
\hline M3-B & Arm & $\begin{array}{l}\text { Educational, entertaining, beneficial for } \\
\text { physical disability }\end{array}$ & We take the healthy & Rag doll \\
\hline M4-G & $\begin{array}{l}\text { Hand and } \\
\text { foot }\end{array}$ & Both developer and distractor & Should not be harmful to health & Baby \\
\hline M5-B & Arm & Tutorial for children's development & Age appropriate & Baby \\
\hline M6-B & Arm and leg & Educational, instructive, & $\begin{array}{l}\text { Child's favorite toy (cartoon } \\
\text { characters) }\end{array}$ & Barbie doll, teddy bear \\
\hline M7-B & Arm and leg & Educational, instructive, & $\begin{array}{l}\text { Child's favorite toy (cartoon } \\
\text { characters) }\end{array}$ & Teddy bear \\
\hline M8-G & Arm and leg & Vehicle to entertain children & To be harmless & Rag doll \\
\hline M9-B & Leg & Vehicle for children & $\begin{array}{l}\text { To be of good quality, to be useful to } \\
\text { the child }\end{array}$ & Car, rag doll \\
\hline M10-B & Foot & $\begin{array}{l}\text { Anything they spend time with can } \\
\text { be toys }\end{array}$ & age appropriate & Bear \\
\hline M11-G & Foot & $\begin{array}{l}\text { An educational tool, useful for your } \\
\text { disability }\end{array}$ & Not having a sharp penetrating side & Baby \\
\hline M12-G & Arm and leg & Educational and entertaining material & Not to harm & Baby \\
\hline M13-B & Leg & $\begin{array}{l}\text { Educational and instructive, useful for } \\
\text { his disability }\end{array}$ & Colors, sounds & Abacus \\
\hline M14-B & Foot & Children's car & Be economical & Ball, puzzle \\
\hline M15-B & Foot & Fun for kid & Colorful toys to play with by hand & Car, toys that make noise \\
\hline M16-G & Leg & Makes it fun to have a good time & $\begin{array}{l}\text { What my daughter wants, can play } \\
\text { with hands }\end{array}$ & Baby car \\
\hline M17-B & Leg & Just let my son spend his time & Be cheap, be harmless & Baby \\
\hline M18-G & Foot & Fun, helpful for your disability & Useful, fun & Baby \\
\hline \multirow[t]{5}{*}{ M19-G } & Arm & Diverting & To be cheap & Baby \\
\hline & & Features highlighted in definitions & Features highlighted in toy selection & $\begin{array}{l}\text { Features highlighted in toy } \\
\text { perception }\end{array}$ \\
\hline & & $\begin{array}{l}\text { Useful (16) } \\
\text { Educational and didactic (10) } \\
\text { Wasting time, distraction (8) } \\
\text { Helpful for Disability (5) }\end{array}$ & $\begin{array}{l}\text { Children's Choice (10) } \\
\text { We choose together (7) } \\
\text { parent choice (2) } \\
\text { Quality and healthy (7) } \\
\text { Age appropriate (3) } \\
\text { Cheap (3) } \\
\text { According to the obstacle (3) } \\
\text { Color and sound (3) }\end{array}$ & $\begin{array}{l}\text { Not gender specific (15) } \\
\text { Color perception (15) } \\
\text { Baby (15) }\end{array}$ \\
\hline & & \multicolumn{3}{|l|}{ Added information about the toy } \\
\hline & & \multicolumn{3}{|c|}{$\begin{array}{l}\text { Let there be more developmental toys for physically disabled people (9) } \\
\text { Quality, healthy and harmless (9) } \\
\text { Educational and developer (5) } \\
\text { Cheap (4) } \\
\text { No hard objects (2) }\end{array}$} \\
\hline
\end{tabular}




\begin{tabular}{|c|c|c|c|}
\hline Teacher & Disability location & Toy definition & Toy selection \\
\hline T1 & A future-proof lifestyle & Cheap, harmless toys that I couldn't get as a kid & Mud car, wire wheel, toy tractor \\
\hline T2 & Any object can be a toy & Not harming the child & Little pink turtle car \\
\hline T3 & The toy is a separate world & $\begin{array}{l}\text { Construction material, perception of the child } \\
\text { (physical-psychological) }\end{array}$ & Ball \\
\hline T4 & $\begin{array}{l}\text { To enable children of the game age to adapt } \\
\text { easily to real life. }\end{array}$ & Must be strong and durable & Figure cat, toy city cars \\
\hline T5 & $\begin{array}{l}\text { All kinds of objects and tools for playing and } \\
\text { having fun }\end{array}$ & $\begin{array}{l}\text { It should be versatile, not hinder the child's } \\
\text { imagination and creativity, and the child should } \\
\text { not fail in the face of toys. }\end{array}$ & $\begin{array}{l}\text { Repair kit with toy bench drill, } \\
\text { dog, baby }\end{array}$ \\
\hline T6 & Toys are children's imaginations & $\begin{array}{l}\text { The toy should stay in the child's interest for a } \\
\text { long time }\end{array}$ & Animals play mat, jigsaw puzzle \\
\hline T7 & $\begin{array}{l}\text { Developing the child's sense of selection, } \\
\text { evaluation and creativity }\end{array}$ & $\begin{array}{l}\text { It should be appropriate for the child's age, } \\
\text { interest and ability. }\end{array}$ & Bowling set, wooden katamino \\
\hline T8 & It's fun & $\begin{array}{l}\text { It is educational and suitable for the level of the } \\
\text { child }\end{array}$ & Maracas, car \\
\hline T9 & Tools for children to develop themselves & To be educational, instructive and practical & Train ball \\
\hline \multirow[t]{5}{*}{ T10 } & $\begin{array}{l}\text { Children having fun, educational ones } \\
\text { educating children }\end{array}$ & $\begin{array}{l}\text { It can be played, the child wants, educational } \\
\text { and quality }\end{array}$ & Car, baby, plane, ball \\
\hline & Features highlighted in definitions & Features highlighted in toy selection & $\begin{array}{l}\text { Features highlighted in toy } \\
\text { perception }\end{array}$ \\
\hline & $\begin{array}{l}\text { Useful (9) } \\
\text { Educational and tutorial (6) } \\
\text { Supporting fine, gross motor and mental } \\
\text { development (4) } \\
\text { Communication tool (1) }\end{array}$ & $\begin{array}{l}\text { Children's Choice (7) } \\
\text { Healthy, high quality, harmless (6) } \\
\text { Color (4) } \\
\text { Easily accessible (4) } \\
\text { Cheap and everyone should Be able to buy it ( } 2 \text { ) }\end{array}$ & $\begin{array}{l}\text { It should be a toy for both } \\
\text { genders (10) }\end{array}$ \\
\hline & \multicolumn{3}{|l|}{ Added information about the toy } \\
\hline & $\begin{array}{l}\text { Children do not discriminate in toys (10) } \\
\text { Tool for getting started in real life (2) } \\
\text { Child should be able to do it himself (1) }\end{array}$ & & \\
\hline
\end{tabular}

\section{DISCUSSION}

Data were collected through structured interviews with 19 children, 19 mothers and 10 teachers in this study, which was conducted to determine the factors affecting the choice of toys for children with physical disabilities. The answers to the nine questions were evaluated in terms of content and gathered under four categories (toy definition, selection, perception and added information about the toy).

In the interview, the children stated that while describing the toy, it should be fun the most. Mothers and their teachers gave the same answer and stated that the toy should be useful first, and educational and instructive second. In addition, another answer given by mothers to this question emphasized that it is beneficial for the child's disability. In addition, the teachers emphasized that the toy should both support fine, gross motor and mental development and be a communication tool. In their study, Adak Özdemir and Ramazan (2012) defined the child's toy as a game tool, entertaining and distraction, while the mother and teacher defined it as child-specific, entertaining, supporting his development and learning (1). Tuğrul et al. (2014) also emphasized that the toys should be educational in nature (3). Similar results were found with this study. However, this research was also conducted on physically disabled children.
In the interview, he stated that when children choose toys, the color is the most, and the second is their own will. Mothers and teachers gave the same answer when choosing toys. He emphasized that the child should choose the toy. Other responses of mothers and teachers to toy selection are similar. He stated that while choosing a toy, it should be accessible to everyone with quality, healthy and cheap features. In the study conducted by Adak Özdemir and Ramazan (2012), results similar to this study were found in terms of emphasizing the feature of being healthy, safe, harmless, suitable for age and price in the answers given by mothers and teachers to the choice of toys (1). In addition, in this study, mothers emphasized that when choosing toys, the child should be chosen according to the place of disability among their characteristics. According to the results of another study, it was determined that mothers pay attention to the price, safety and quality features, being an educator and developer (17).

In the interview, it was emphasized that the answers given by the children to the toy perception were gender specific, respectively. The response of mothers and teachers to the perception of toys emphasized that it is not gender specific and that it should be a toy that both genders can play with. However, the answers in Karaca (2020)'s study are different from this research (17). Mothers' awareness of the necessity of the toy for the 
child is similar in that they emphasize the peculiarity of the toy for the child.

Among the added information about the toy in this research, another feature that children, mothers and teachers emphasized most about the toy was that the toy should be suitable for the disability. His children emphasized that the toy should be 'according to my mobility and disability'. Among the additional information about the toys, the mothers answered, "Let there be more developmental toys for physically disabled individuals".

\section{CONCLUSION}

As a result, in this study, it was found that the toy choice of physically disabled children affected the toy choice of children, especially mothers. It was emphasized that children should be able to move freely and comfortably according to their physical disability related to the toy, and that mothers should be according to the child's disability. Especially mothers said that toys should be made more developmental toys for physically disabled individuals. In addition to these, they emphasized that while defining a child's toy, it should be fun, while mothers and teachers should first be educational, instructive and useful.

\section{Limitations}

The research is limited to the sample group, it is collected only according to the mother's statement as parents, and the research is conducted in a single province. In addition, it is recommended to conduct studies in other places with a large sample size and different socioeconomic levels.

\section{ETHICAL DECLARATIONS}

Ethics Committee Approval: The study was carried out with the permission of Karamanoğlu Mehmetbey University, Faculty of Health Science Non-interventional Clinical Research Ethics Committee (Date: 28.11.2018, Decision No: 10/2018-38).

Informed Consent: All patients signed the free and informed consent form.

Referee Evaluation Process: Externally peer-reviewed. Conflict of Interest Statement: The authors have no conflicts of interest to declare.

Financial Disclosure: The authors declared that this study has received no financial support.

Author Contributions: All of the authors declare that they have all participated in the design, execution, and analysis of the paper, and that they have approved the final version.

\section{REFERENCES}

1. Adak Özdemir A, Ramazan O. Attitudes of child, mother and teacher towards toy. J Educ Sci Res 2012;2(1):1-16.

2. Ayan S, Memiş UA, Eynur BR, Kabakçı A. Özel eğitime ihtiyaç duyan çocuklarda oyuncak ve oyunun önemi. Uluslararası Hakeml Akademik Spor Sağlık Ve Tıp Bilimleri Derg 2012;2(4):80-9.

3. Tuğrul B, Metin Aslan Ö, Ertürk HG, Özen Altınkaynak Ş. Anaokuluna devam eden altı yaşındaki çocuklar ile okul önces öğretmenlerinin oyun hakkındaki görüşlerinin incelenmesi. İnönü Üniversitesi Eğitim Fakültesi Derg 2014;15(1):97-116.

4. Pehlivan H. Oyun ve öğrenme. Ankara: Anı Yayıncılık; 2005.

5. Ummanel A. A comparative analysis of children's, mothers' and teachers' views about play and toys. Uluslararası Beşeri Bilimler ve Eğitim Derg 2017;3(2):222-41.

6. Oktay A. Yaşamın sihirli yılları: Okul öncesi dönem. İstanbul: Epsilon Yayınları; 2002.

7. Landreth G, Homeyer L, Morrison M. Play as the language of children's feelings. Play from birth to twelve. Contexts, perspectives and meanings; 2006.

8. Avcu AU. 0-2 yaş bebeği olan annelerin oyuncak tercihlerinin incelenmesi. Int J Soc Educ Sci 2015;2(4):37-46.

9. Özyürek A, Akça F. Zihinsel yetersizliği olan çocukların oyuncak profillerinin incelenmesi. Bartın University Journal of Faculty of Education 2015;4(2):516-29.

10. Blakemore JEO, Centers RE. Characteristics of boys' and girls' toys. Sex Roles 2005;53:619-33.

11. Aksoy P, Baran G. Annelerin cinsiyet rollerine ilişkin özellikleri ile çocukların oyuncak tercihleri ve oynadıkları oyun türleri arasındaki ilişki üzerine bir çalışma. Eğitimde Nitel Araştırmalar Derg 2017;5(1):102-36.

12. Caldera YM, Huston AC, O'Brien M. Social interactions and play patterns of parents and toddlers with feminine, masculine, and neutral toys. Child Dev 1989;60:70-6.

13. Demirkaya G, Kömleksiz FÖ, Özdemir S. Okul öncesi dönemde çocuğu olan anne-babaların geçmişte kullandıkları oyuncaklar ve oyuncak seçiminde dikkat ettikleri unsurlar. Kastamonu Eğitim Derg 2018;26(6):2001-09.

14. Yıldırım A, Şimşek H. Sosyal bilimlerde nitel araştırma yöntemleri. Ankara: Seçkin Yayıncılık; 2005.

15. Patton MQ. Qualitative research and evaluation methods (3rd ed.), California: Sage Publications; 2002.

16. Venkatesan S, Yashodharakumar GY. Parent opinions and attitudes on toys for children with or without developmental disabilities. Int J Indian Psychol 2017;4(4):6-20.

17. Karaca NH. 36-72 aylar arasinda çocuğu olan annelerin oyuncak seçimindeki görüşlerinin incelenmesi. Çocuk ve Gelişim Derg 2020;3(5):29-40.

18. Bilgin N. Sosyal bilimlerde içerik analizi. Ankara: Siyasal Kitabevi; 2006. 